\title{
Pendugaan stok dan musim penangkapan ikan julung-julung dengan soma roa di perairan Tagulandang, Kabupaten Kepulauan Siau Tagulandang Biaro
}

\author{
An estimation of garfish stock and its fishing season in Tagulandang waters, \\ Siau Tagulandang Biaro Regency \\ Elyezer KAWIMBANG, ISROJATy J. PARANSA* dan MARIANA E. KAYAdOE \\ Program Studi Pemanfaatan Sumberdaya Perikanan, Fakultas Perikanan dan Ilmu Kelautan, \\ Universitas Sam Ratulangi, Manado 95115
}

\begin{abstract}
Garfish (Hemirhamphus far) locally known as "roa" are traditionally smoked commonly called "galafea". The garfish migrating to spawn in Tagulandang waters, indicated with mature state of eggs, makes their body weight increase and movements become slow which make them easily caught by "soma roa" (type of fish net). When the fishing is done constantly their population tends to be pushed down since their life cycle is being disrupted. The purposes of this study were (1) to predict the potential for sustainable Garfish resources in the Tagulandang waters and (2) to analyze the fishing season of the garfish with soma roa in Tagulandang waters. The method used was descriptive based on case studies. Data collection was done through interviews with local fishermen, recording trip data and hauling operation and direct observation. Estimating the fish stock used a Schaefer model (1954) is Catch $\mathrm{MSY}_{\mathrm{MS}}=-0.25 \times \mathrm{a}^{2} / \mathrm{b}$ and $\mathrm{F}_{\mathrm{opt}}\left(\mathrm{E}_{\mathrm{MSY}}\right)=-0.5 \times \mathrm{a} / \mathrm{b}$, and estimating the fish season $\mathrm{Y}_{\mathrm{i}}$ was determined by comparing the average total catch (), where if: $\mathrm{Y}_{\mathrm{i}}>$ mean, the fishing season or $\mathrm{Y}_{\mathrm{i}}<$ mean, no fishing season. The results showed that the potential for sustainable fishing in the Tagulandang waters for the garfish had $\mathrm{C}_{\mathrm{MSY}}$ of 11,716 tons per year with optimum effort $\mathrm{E}_{\mathrm{MSY}}$ of 144,643 trips. Resource utilization rate reached $98.55 \%$, which means that the utilization of the balance point almost reached the maximum sustainable levels so that additional efforts could be harmful to the extinction of the resource. Fishing season of garfish in Tagulandang waters was divided into two phases, the middle of the year, early April and late phase of the year, September and October.
\end{abstract}

Keywords: garfish, stock, season

\begin{abstract}
ABSTRAK
Ikan julung-julung (Hemirhamphus far) atau ikan roa yang oleh masyarakat diolah secara tradisional dengan cara pengasapan, yang dikenal dengan nama galafea. Gerombolan ikan roa mengadakan migrasi ke perairan Tagulandang untuk melakukan pemijahan karena ikan yang tertangkap hampir seluruhnya dalam kondisi hampir bertelur. Dalam kondisi matang gonad ini tubuh ikan menjadi berat dan gerakan renang ikan menjadi lambat, pada saat inilah ikan ditangkap dengan soma roa. Bila penangkapan ikan ini dilakukan terus-menerus dikuatirkan populasinya cenderung berkurang karena siklus hidupnya dapat terganggu. Tujuan dari penelitian ini adalah (1) menduga potensi lestari sumberdaya ikan julung-julung di perairan Tagulandang dan (2) menganalisa musim penangkapan ikan julungjulung dengan soma roa di perairan Tagulandang. Penelitian ini menggunakan metode deskriptif berdasarkan studi kasus. Data dikumpulkan dengan cara wawancara terhadap nelayan setempat, melakukan pencatatan data tentang trip operasi dan hasil tangkapan, pengamatan langsung dan partisipasi aktif. Pendugaan stok menggunakan model Schaefer (1954) dimana Catch ${ }_{M S Y}=-0.25 \times \mathrm{a}^{2} / \mathrm{b}$ dan $\mathrm{F}_{\mathrm{opt}}\left(\mathrm{E}_{\mathrm{MSY}}\right)=-0.5 \times \mathrm{a} / \mathrm{b}$, dan untuk menduga musim ikan dapat diketahui dengan membandingkan $\mathrm{Y}_{\mathrm{i}}$ dengan rata-rata hasil tangkapan total $(\bar{Y})$, dimana jika $\mathrm{Y}_{\mathrm{i}}>\bar{Y}$ berarti musim ikan atau $\mathrm{Y}_{\mathrm{i}}<\bar{Y}$ berarti tidak musim ikan. Potensi lestari ikan julung-julung di perairan Tagulandang 11,716 ton pertahun dengan upaya optimum 144,643 trip. Tingkat pemanfaatan mencapai 98,55\%, sehingga penambahan alat tangkap akan mengganggu kelestarian ikan julung-julung. Musim penangkapan di perairan Tagulandang terjadi
\end{abstract}

\footnotetext{
* Alamat untuk penyuratan: e-mail: isrojaty@yahoo.com
} 
dalam dua fase yaitu fase pertama terjadi pada bulan Februari sampai April dan fase kedua terjadi pada bulan Agustus sampai Oktober.

Kata-kata kunci: julung-julung, stok, musim

\section{PENDAHULUAN}

\section{Latar Belakang}

Di perairan Tagulandang terdapat salah satu sumberdaya laut pelagis kecil yang mempunyai nilai ekonomis penting yakni ikan julung-julung (Hemirhamphus far) atau ikan roa (Gbr. 1) yang oleh masyarakat diolah secara tradisional dengan cara pengasapan. Hasil olahan tersebut dikenal dengan nama lokal galafea, dan sangat digemari oleh masyarakat karena rasanya yang khas.

Menurut Reppie dan Luasunaung (2001) ikan roa adalah ikan pelagis yang hidup di perairan pantai ke arah lepas pantai dan hanya terlihat bergerombol di sekitar perairan karang ketika akan memijah karena ikan ini melepaskan telur di terumbu karang yang subur dan memiliki sumber makanan alami bagi induk maupun anakan ikan roa. Gerombolan ikan roa yang mengadakan migrasi ke perairan ini untuk melakukan pemijahan karena ikan yang tertangkap hampir seluruhnya dalam kondisi hampir bertelur. Dalam kondisi matang gonad ini tubuh ikan menjadi berat dan gerakan renang ikan menjadi lambat, pada saat inilah ikan ditangkap dengan soma roa.

Soma roa adalah alat tangkap dari bahan utama jaring, tali temali serta pelampung dan pemberat yang bagian-bagiannya terdiri dari sayap, bahu dan kantong yang ditujukan khusus untuk menangkap ikan roa. Prinsip penangkapan alat ini menyerupai soma pajeko yaitu ditebarkan mengelilingi gerombolan ikan sehingga membentuk dinding penghalang yang berfungsi untuk mencegah ikan agar tidak keluar dari jaring.

Bila penangkapan ikan ini dilakukan terusmenerus dikuatirkan populasinya cenderung berkurang karena siklus hidupnya dapat terganggu bila tanpa diikuti dengan pertumbuhan dan reproduksi; bahkan tidak ada lagi habitat yang kondusif untuk melepaskan telur. Kalau populasi cenderung berkurang bahkan sampai tidak ada sama sekali, maka akan berdampak pula pada perekonomian masyarakat nelayan.

\section{Tinjauan Pustaka}

Menurut Handoyo (2011), ikan pelagis adalah kelompok ikan yang sebagian besar hidupnya berada pada lapisan permukaan hingga kolom air (mid layer). Ikan pelagis ini memiliki ciri khas, yaitu dalam beraktivitas umumnya membentuk gerombolan (schooling) dan melakukan migrasi untuk berbagai kebutuhan hidupnya (Simbolon, 2011). Ikan pelagis dibagi dalam dua kelompok yaitu: (1) ikan pelagis besar dengan ukuran 100$250 \mathrm{~cm}$ (ukuran dewasa). Ikan ini umumnya perenang cepat, seperti: tongkol, cakalang, tuna, tenggiri dan lain-lain. (2) Ikan pelagis kecil yang berukuran $5-50 \mathrm{~cm}$ (ukuran dewasa) seperti: ikan teri, kembung, selar, ikan terbang dan sebagainya. Widodo et al (1994) dalam Simbolon (2011) menyatakan bahwa ikan pelagis kecil mempunyai karakteristik sebagai berikut:

1. Membentuk gerombolan yang berpencarpencar,

2. Variasi rekruitmen cukup tinggi dan hal ini sangat erat kaitannya dengan kondisi lingkungan yang labil,

3. Selalu beruaya baik secara temporal maupun spasial,

4. Aktifitas pergerakan cukup tinggi yang ditunjukkan oleh bentuk badannya yang menyerupai torpedo,

5. Kulit dan tekstur dagingnya mudah rusak, kadar lemak dagingnya relatif tinggi, sehingga kualitasnya cepat menurun dan membusuk.

Menurut Reppie dkk (2011) ikan julung-julung tergolong jenis ikan pelagis hidup di perairan pantai dan cenderung oceanis yang umumnya tersebar di perairan Indonesia Timur yang berkadar garam tinggi. Ikan julung-julung memiliki klasifikasi menurut petunjuk Saanin (1984) dalam Sumlang (2009) adalah sebagai berikut:

Phylum : Vertebrata

Class : Teleostomi

Famili : Hemirhamphidae

Genus : Hemirhamphus

Spesies : Hemirhamphus far

Soma roa sangat mirip dengan pukat cincin mini (small purse seine). Perbedaan utama antara keduanya adalah soma roa ukurannya lebih kecil dari pada pukat cincin mini, tetapi ratio perbandingan ukuran panjang dan dalam jaring 
jauh lebih besar pada soma roa, serta cincinnya langsung diikatkan pada tali ris bawah (Reppie dan Lalamentik, 2000). Badan jaring terdiri dari bagian-bagian kantong, bahu dan sayap. Ukurannya sangat bervariasi karena tergantung pada keinginan nelayan dan ketersediaan dana untuk membuatnya.

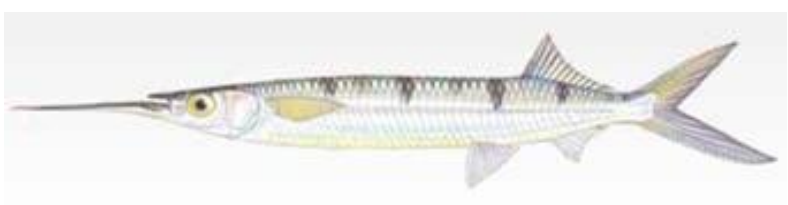

Gambar 1. Ikan Julung-julung (Hemirhampus far) di perairan Tagulandang

Widodo dan Sunardi (2006) menyatakan bahwa model Schaefer memandang yield (catch, in weight) per unit effort (hasil tangkapan per satuan upaya, CPUE) merupakan fungsi dari upaya penangkapan, sehingga ditulis:

$$
\frac{Y(i)}{f(i)}=a+b \times f_{(i)}
$$

Data $\mathrm{f}_{\mathrm{i}}$ merupakan data effort tahun $\mathrm{i}, \mathrm{i}=1,2, \ldots, \mathrm{n}$, $\mathrm{n}=7,(\mathrm{Y} / \mathrm{f})_{\mathrm{i}}$ adalah CPUE tahun i. Bila $\mathrm{f}(\mathrm{i}) \leq-\mathrm{a} / \mathrm{b}$, slope $\mathrm{b}$ harus negatif. Intersep a adalah nilai $\mathrm{Y} / \mathrm{f}$ yang diperoleh sesaat setelah kapal pertama melakukan penangkapan untuk pertama kali. Oleh karena itu, intersep tersebut harus positif, sehingga, $-\mathrm{a} / \mathrm{b}$ adalah positif dan $\mathrm{Y} / \mathrm{f}$ adalah nol untuk $\mathrm{f}=-\mathrm{a} / \mathrm{b}$. Akibat suatu nilai negatif dariY/f (CPUE) tidak masuk akal sehingga model ini hanya dapat diterapkan untuk nilai $\mathrm{f} 3 / 4-\mathrm{a} / \mathrm{b}$.

\section{METODOLOGI PENELITIAN}

Bahan dan Alat yang dipakai pada penelitian ini yaitu: Alat tangkap Soma roa, panjang 230,64 m dan lebar $12 \mathrm{~m}$, Perahu tipe lambut, panjang 12,38 $\mathrm{m}$, lebar 2,46 $\mathrm{m}$, dan dalam 1,4 m, Motor penggerak Yamaha $25 \mathrm{HP}$ dan $15 \mathrm{HP}$, Bahan bakar minyak tanah dan bensin, Oli, Meteran, Alat tulis menulis, dan Kamera.

Menurut Nasir (1985) dasar metode yang digunakan dalam penelitian ini adalah metode deskriptif berdasarkan studi kasus. Teknik pengumpulan data dikerjakan dengan cara wawancara terhadap nelayan setempat, melakukan pencatatan data tentang trip operasi dan hasil tangkapan dan pengamatan langsung.

\section{Teknik analisa data}

Pendugaan stok sumber daya ikan julung-julung yang berada di perairan Tagulandang digunakan model Schaefer (1954) adalah Catch ${ }_{\mathrm{MSY}}=-0,25 \times$ $\mathrm{a}^{2} / \mathrm{b}$ dan $\mathrm{F}_{\text {opt }}\left(\mathrm{E}_{\mathrm{MSY}}\right)=-0,5 \times \mathrm{a} / \mathrm{b}$ dan untuk menduga musim ikan dapat diketahui dengan membandingkan $Y . j$ dengan rata-rata hasil tangkapan total $(\bar{Y})$, dimana jika Y.j $>\bar{Y}$ berarti musim ikan atau Y.j $<\bar{Y}$ berarti tidak musim ikan.

\section{Deskripsi alat}

Soma roa yang dibuat oleh nelayan setempat memiliki panjang 230,66 m dan lebar $12 \mathrm{~m}$. Konstruksi dari alat ini terdiri dari sayap, bahu dan kantong serta pemberat dari timah yang sekaligus berfungsi sebagai cincin yang diikatkan langsung pada tali ris bawah dengan benang PA Cf 210 $\mathrm{D} \times 15$. Bahan jaring menggunakan bahan polyamida (PA) continous filament $(\mathrm{Cf})$ yaitu $\mathrm{PA}$ Cf 210 Dx6. Bagian yang lain ialah tali ris atas, tali ris bawah, tali pelampung, tali pemberat, tali kolor, pelampung (pelampung synthetic rubber dan pelampung tanda), dan pemberat cincin.

Perahu yang digunakan dalam operasi penangkapan adalah perahu tipe lambut mempunyai ukuran panjang $12,38 \mathrm{~m}$, lebar 2,46 m, dan dalam $1,4 \mathrm{~m}$. Perahu ini menggunakan tenaga penggerak 2 buah motor tempel dengan kekuatan 15 HP dan 25 HP yang keduanya bermerek Yamaha dengan bahan bakar utama minyak tanah dan bensin sebagai pancingan ketika mesin akan dihidupkan. Alat bantu penangkapan yaitu sibusibu (serok), galah, penggait tali dan alat bantu tambahan.

\section{HASIL DAN PEMBAHASAN}

\section{Pendugaan Stok}

Pendugaan stok sumberdaya ikan julung-julung yang berada di perairan Tagulandang digunakan dengan model produksi, yaitu hubungan antara hasil tangkapan (C) dengan upaya penangkapan (f). Asumsi yang melandasi hubungan tersebut adalah CPUE dengan model matematis menurut Gulland (1983) dan disederhanakan oleh Schaefer (1954) sebagai berikut $\mathrm{Catch}_{\mathrm{MSY}}=-0,25 \times \mathrm{a}^{2} / \mathrm{b}$ dan $\mathrm{F}_{\mathrm{opt}}\left(\mathrm{Effort}_{\mathrm{MSY}}\right)=-0,5 \times \mathrm{a} / \mathrm{b}$.

Berdasarkan rumus tersebut maka dilakukan pengolahan data sesuai ketersediaan data tangkapan dan upaya penangkapan dalam lima tahun, yaitu tahun 2006-2010 dan ditampilkan pada Tabel 2. 
Tabel 1. Spesifikasi soma roa

\begin{tabular}{|c|c|c|c|c|c|c|c|c|c|c|}
\hline & & & & & BAHAN & ARING & & & & \\
\hline Perincian & & Material & & twine & \# (mm) & Panja & ang & & Lebar & $\mathrm{E}$ \\
\hline & & & & & & $\mathrm{m}$ & $\sum \#$ & $\mathrm{~m}$ & $\sum \#$ & $\%$ \\
\hline SAYAP & & & & & & & & & & \\
\hline A1 & & PA cf & 210 & Dx6 & 37,50 & 10,86 & 400 & 3,42 & 132 & 72,38 \\
\hline A2 & & PA cf & 210 & Dx6 & 37,50 & 10,67 & 400 & 4,01 & 152 & 71,11 \\
\hline A3 & & PA cf & 210 & Dx6 & 37,50 & 10,67 & 400 & 4,59 & 174 & 71,11 \\
\hline A4 & & PA cf & 210 & Dx6 & 37,50 & 10,67 & 400 & 5,27 & 200 & 71,11 \\
\hline A5 & & PA cf & 210 & Dx6 & 37,50 & 10,50 & 400 & 6,05 & 226 & 70,00 \\
\hline A6 & & PA cf & 210 & Dx6 & 37,50 & 10,50 & 400 & 7,86 & 250 & 70,00 \\
\hline BAHU & & & & & & & & & & \\
\hline B1 & & PA cf & 210 & Dx6 & 25,00 & 6,18 & 400 & 7,86 & 400 & 61,82 \\
\hline B2 & & PA cf & 210 & Dx6 & 25,00 & 6,18 & 400 & 8,84 & 450 & 61,82 \\
\hline B3 & & PA cf & 210 & Dx6 & 25,00 & 6,10 & 400 & 8,91 & 450 & 61,82 \\
\hline B4 & & PA cf & 210 & Dx6 & 25,00 & 6,00 & 400 & 11,00 & 550 & 60,00 \\
\hline KANTONG & & & & & & & & & & \\
\hline $\mathrm{C} 1$ & & PA cf & 210 & Dx6 & 25,00 & 6,00 & 400 & 12,00 & 600 & 60,00 \\
\hline $\mathrm{C} 2$ & & PA cf & 210 & Dx6 & 25,00 & 6,00 & 400 & 12,00 & 600 & 60,00 \\
\hline $\mathrm{C} 3$ & & PA cf & 210 & Dx6 & 25,00 & 6,00 & 400 & 12,00 & 600 & 60,00 \\
\hline $\mathrm{C} 4$ & & PA cf & 210 & Dx6 & 25,00 & 6,00 & 400 & 12,00 & 600 & 60,00 \\
\hline $\mathrm{C} 5$ & & PA cf & 210 & Dx6 & 25,00 & 6,00 & 400 & 12,00 & 600 & 60,00 \\
\hline C6 & & PA cf & 210 & Dx6 & 25,00 & 6,00 & 400 & 12,00 & 600 & 60,00 \\
\hline $\mathrm{C} 7$ & & PA cf & 210 & Dx6 & 25,00 & 6,00 & 400 & 12,00 & 600 & 60,00 \\
\hline $\mathrm{C} 8$ & & PA cf & 210 & Dx6 & 25,00 & 6,00 & 400 & 12,00 & 600 & 60,00 \\
\hline $\mathrm{C} 9$ & & PA cf & 210 & Dx6 & 25,00 & 6,00 & 400 & 12,00 & 600 & 60,00 \\
\hline & & & & & TALI TH & MALI & & & & \\
\hline Perincian & & Material & & Diame & $\mathrm{mm})$ & Panjang (m) & $\mathrm{Ju}$ & lah (buah & & \\
\hline Tali Ris A & Atas & $\mathrm{PE}$ & & 6 & & 230,64 & & 1 & & \\
\hline Tali Pelan & mpung & PE & & 6 & & 230,64 & & 1 & & \\
\hline Tali Ris B & Bawah & PE & & 4 & & 230,64 & & 1 & & \\
\hline Tali Pemb & berat & $\mathrm{PE}$ & & 6 & & 230,64 & & 1 & & \\
\hline Tali Kolor & & $\mathrm{PE}$ & & 1 & & 300,00 & & 1 & & \\
\hline & & & & & MPUNG & DAN CINCII & & & & \\
\hline Perincian & Mat & terial & Bentuk & $\begin{array}{r}\text { Diam } \\
(\mathrm{cm}\end{array}$ & - Berat & li Udara D & $\begin{array}{c}\text { Daya Teng } \\
\text { (gf) }\end{array}$ & gelam & $\begin{array}{l}\text { Daya Apung } \\
\text { (gf) }\end{array}$ & $\begin{array}{l}\text { Jumlah } \\
\text { (buah) }\end{array}$ \\
\hline Pelampung & Rubbe & & Bulat & 6,6 & & 1,59 & - & & 33,77 & 7718 \\
\hline & PVC & & Bulat & 18,0 & & - & - & & 540,00 & 1 \\
\hline & PVC & & Bulat & 10,0 & & - & - & & 300,00 & 1 \\
\hline Cincin & Timal & h Hitam & Bulat & 6,0 & & 8,00 & 162,32 & & - & 173 \\
\hline
\end{tabular}


Tabel 2. CPUE ikan julung-julung di perairan Tagulandang selama 5 (lima) tahun

\begin{tabular}{lccc}
\hline Tahun & Catch (ton) & Effort $(\mathrm{X})$ & CPUE $(\mathrm{Y})$ \\
\hline 2006 & 10,476 & 174 & 0,060 \\
2007 & 12,954 & 151 & 0,086 \\
2008 & 12,055 & 140 & 0,086 \\
2009 & 10,813 & 129 & 0,084 \\
2010 & 11,492 & 126 & 0,091 \\
\hline Total & 57,790 & 720 & 0,407 \\
Rataan & 11,558 & 144 & 0,081 \\
\hline
\end{tabular}

Untuk menghitung konstanta slope b dan konstanta intercept a, maka data dianalisis lanjut menjadi seperti Tabel 3.

Tabel 3. Deviasi effort dan CPUE soma roa

\begin{tabular}{lcrrrrr}
\hline Tahun & Effort & $(X-\bar{X})$ & $(X-\bar{X})^{2}$ & CPUE & $(Y-\bar{Y})(X-\bar{X})(Y-\bar{Y})$ \\
& $X$ & & & \multicolumn{1}{c}{$Y$} \\
\hline 2006 & 174 & 30 & 900 & 0,060 & $-0,021$ & $-0,630$ \\
2007 & 151 & 7 & 49 & 0,086 & 0,004 & 0,028 \\
2008 & 140 & -4 & 16 & 0,086 & 0,004 & $-0,016$ \\
2009 & 129 & -15 & 225 & 0,084 & 0,003 & $-0,003$ \\
2010 & 126 & -18 & 324 & 0,091 & 0,010 & $-0,180$ \\
\hline Total & 720 & - & 1514 & 0,407 & - & $-0,857$ \\
Rataan & 144 & - & - & 0,081 & - & - \\
\hline
\end{tabular}

Berdasarkan data dalam Tabel 2 maka hasil tangkapan maksimum lestari $\left(\mathrm{C}_{\mathrm{MSY}}\right)$ dan upaya optimum $\left(\mathrm{F}_{\mathrm{MSY}}\right)$ diduga dengan menggunakan langkah-langkah yang dikemukakan oleh Sparre dan Venema (1999) diperoleh nilai untuk konstanta $\mathrm{b}=$ slope $(\mathrm{Yi}, \mathrm{Xi})=-0,056^{-2}$ dan konstanta $\mathrm{a}=$ intercept $(\mathrm{Yi}, \mathrm{Xi})=0,162$. Hasil tangkapan maksimum lestari menurut model Schaefer adalah sebesar 11,716 ton per tahun. dan usaha optimum adalah 144,643 trip yang kemudian digambarkan dalam kurva yang dapat dilihat pada Gbr. 2.

Hasil regresi dengan menggunakan model Schaefer terhadap data CPUE dan effort menunjukkan nilai estimasi effort optimum yang diperbolehkan dalam usaha penangkapan ikan roa diperairan Tagulandang agar tetap lestari yakni 144,643 trip per tahun dengan nilai estimasi MSY 11,716 ton per tahun, yang berarti bahwa potensi maksimum lestari per unit effort adalah 0,081 ton. Sehingga persamaan regresi dapat dilihat pada Gbr. 3.

Dari kurva regresi dapat dijelaskan bahwa semakin banyak upaya (effort), maka semakin berkurang jumlah hasil tangkap ikan julung-julung pada tiap tangkapan (CPUE). Apabila keadaan ini terus dibiarkan, maka akibatnya stok ikan yang ada di perairan Tagulandang akan semakin berkurang, bahkan pada saatnya akan kehabisan stok.

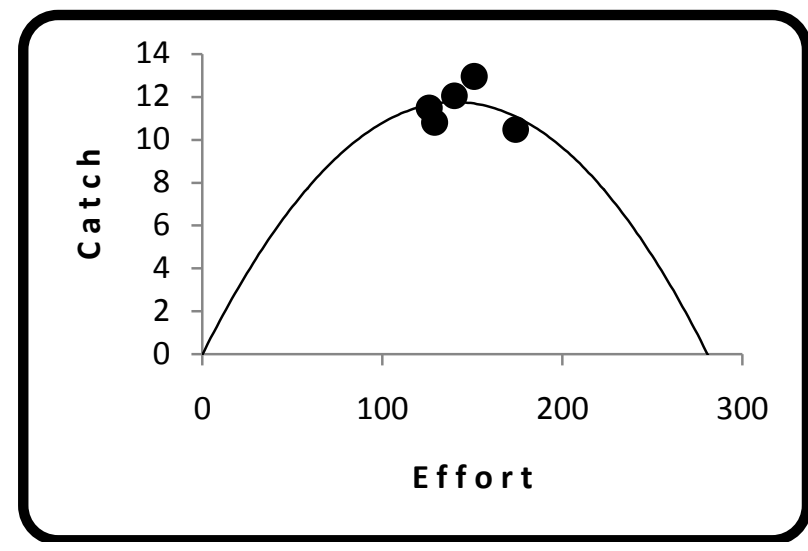

Gambar 2. Kurva MSY Model Schaefer

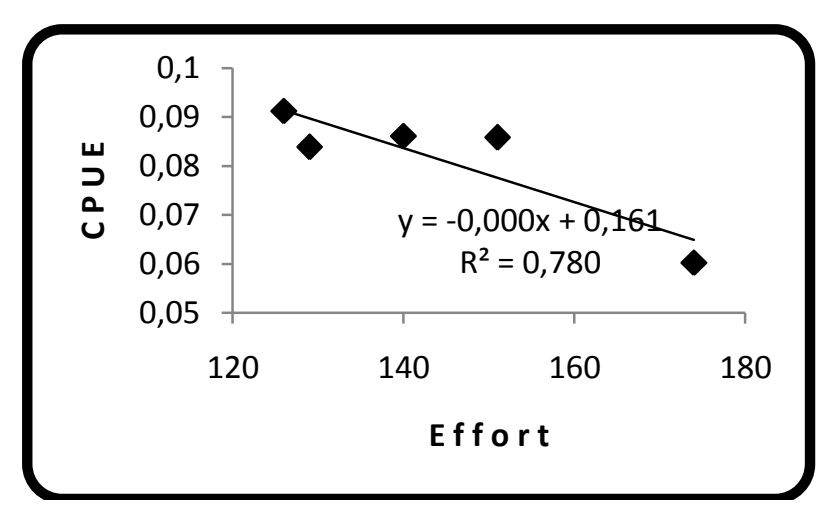

Gambar 3. Kurva Regresi CPUE terhadap effort di Perairan Tagulandang selama 5 tahun.

Pendugaan berdasarkan hasil analisa yaitu 11,716 ton per tahun jika dibahagi 12 bulan, hasil tangkapan sekitar $976 \mathrm{~kg} / \mathrm{bulan}$ atau hampir mencapai 1 ton dimana tangkapan ini didapatkan dengan upaya sebanyak 144 trip per tahun atau 12 trip per bulan. Tingkat pemanfaatan potensi sumberdaya mencapai $98,55 \%$, yang berarti bahwa pemanfaatan potensi hampir mencapai tingkatan titik keseimbangan maksimum lestari sehingga penambahan upaya dapat berbahaya terhadap kepunahan sumberdaya.

\section{Pendugaan musim penangkapan ikan}

Menurut Uktolseja (1993) secara sederhana musim ikan dalam setiap tahun merupakan periode 
(bulan) di mana jumlah hasil tangkapan lebih besar dari rata-rata hasil tangkapan bulanan selama periode tahun tersebut. Analisis yang digunakan untuk menduga musim ikan adalah sebagai berikut:

$$
Y_{._{j}}=\frac{1}{t} \sum Y_{i j}
$$

dimana Y.j adalah rata-rata hasil tangkapan bulanan selama periode $\mathrm{t}$ tahun; dan $\Sigma Y_{i j}$ adalah produksi bulanan pada bulan ke-j tahun-i

Musim ikan dapat diketahui dengan membandingkan $Y . j$ dengan rata-rata hasil tangkapan total $(\bar{Y})$, dimana jika Y.j $>\bar{Y}$ berarti musim ikan; dan $Y . j<\bar{Y}$ berarti tidak musim ikan Nilai $\bar{Y}$ dapat dicari dengan $\bar{Y}=\frac{1}{n} \Sigma Y_{i j}$, dimana $\mathrm{n}$ $=\Sigma n_{i}=4$ bulan ( 1 tahun).

Musim penangkapan ikan julung-julung di perairan Tagulandang dari tahun 2006 sampai dengan tahun 2010 seperti yang ditampilkan pada Gbr. 4, menunjukkan bahwa bulan musim penangkapan ikan julung-julung sepanjang lima tahun, terjadi dalam dua fase yakni dari awal tahun menuju pertengahan tahun dan bulan musim penangkapan yang terjadi menuju akhir tahun. Bulan musim penangkapan dengan hasil tangkapan tertinggi terjadi pada tahun 2009 di bulan September dan diikuti tahun 2010 bulan Juni, dimana pada tahun 2010 terjadi pergeseran bulan musim penangkapan, yang terjadi pada pertengahan tahun.

Musim penangkapan ini secara umum bervariasi setiap tahun yang dibagi dalam dua fase yaitu fase pertama terjadi pada bulan Februari, Maret dan April dan fase kedua terjadi pada bulan Agustus, September dan Oktober. Walaupun pada pertengahan tahun terjadi musim penangkapan, yaitu pada bulan Mei sampai Juli. Dari hasil pengamatan dan pengalaman nelayan bahwa tangkapan terbanyak ketika adanya indikatorindikator seperti umur bulan dilangit, riak-riak perairan warna perairan, kecepatan dan arah arus dan angin. Dengan adanya indikator-indikator ini nelayan banyak memperoleh hasil tangkapan. Sedangkan pada bulan bukan musim penangkapan ditandai dengan bertiupnya angin timur laut yang menyebabkan berkurangnya hasil tangkapan.

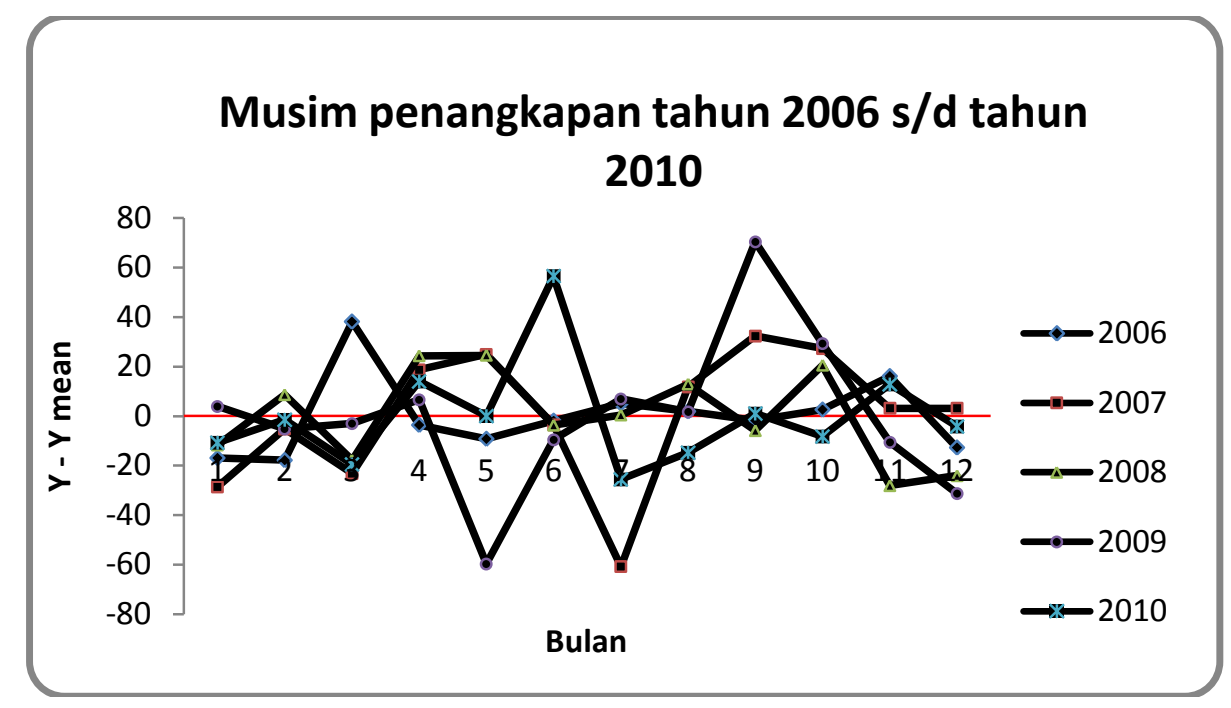

Gambar 4. Musim penangkapan ikan julung-julung di Tagulandang tahun 2006 s/d tahun 2010 
E. Kawimbang dkk.

Tabel 4. Catch per unit effort ikan julung-julung dan deviasinya tahun 2006-2010

\begin{tabular}{|c|c|c|c|c|c|c|c|}
\hline Bulan & $\begin{array}{l}\text { Catch } \\
(\mathrm{kg})\end{array}$ & $\begin{array}{cc}\text { Jumlah } & \text { CPUE Y } \\
\text { upaya } & (\mathrm{kg} / \text { trip}) \\
\text { (Effort, } & \\
\text { trip) } & \end{array}$ & $\begin{array}{l}\text { Selisih } \\
(\mathrm{Y}-\overline{\mathrm{Y}})\end{array}$ & Bulan & Catch $(\mathrm{kg})$ & $\begin{array}{cc}\text { Jumlah } & \text { CPUE Y } \\
\text { upaya } & \text { (kg/trip) } \\
\text { (Effort, } & \\
\text { trip) } & \end{array}$ & $\begin{array}{c}\text { Selisih } \\
(\mathrm{Y}-\overline{\mathrm{Y}})\end{array}$ \\
\hline 2006 & & & & 2008 & & & \\
\hline Januari & 522,3 & 1243,5 & $-16,9$ & Agustus & 1154,3 & 1296,2 & 12,9 \\
\hline Februari & 767,7 & 1842,7 & $-17,8$ & September & 696,1 & 977,3 & $-5,9$ \\
\hline Maret & 1478,3 & 1598,6 & 38,1 & Oktober & 1453,0 & 14103,8 & 20,5 \\
\hline April & 852,3 & 1556,8 & $-3,6$ & November & 496,5 & 955,2 & $-28,1$ \\
\hline Mei & 769,2 & 1551,3 & $-9,2$ & Desember & 414,2 & 759,2 & $-24,1$ \\
\hline Juni & 702,8 & 1258,6 & $-1,9$ & Total & 12055,3 & 140999,1 & \\
\hline Juli & 1377,1 & 2165,6 & 5,1 & Rataan & 1004,6 & $11,783,3$ & \\
\hline Agustus & 748,3 & 1262,4 & 1,9 & 2009 & & & \\
\hline September & 1056,3 & 1858,7 & $-1,8$ & Januari & 343,3 & 485,8 & 4,0 \\
\hline Oktober & 567,0 & 963,0 & 2,6 & Februari & 460,7 & 676,8 & $-5,1$ \\
\hline November & 918,6 & 1276,6 & 16,1 & Maret & 1182,4 & 1578,8 & $-3,0$ \\
\hline Desember & 716,1 & 1547,7 & $-12,7$ & April & 1592,7 & 1888,5 & 6,6 \\
\hline Total & 1047,6 & 174725,3 & & Mei & 266,3 & 1222,2 & $-59,7$ \\
\hline Rataan & 873,0 & $14,560,4$ & & Juni & 650,0 & 972,2 & $-9,6$ \\
\hline 2007 & & & & Juli & 888,8 & 1088,9 & 7,0 \\
\hline Januari & 510,0 & 956,7 & -28.5 & Agustus & 1087,7 & 1383,7 & 1,8 \\
\hline Februari & 640,7 & 880,1 & $-5,2$ & September & 2131,5 & 14152,3 & 70,4 \\
\hline Maret & 806,8 & 1362,1 & $-23,2$ & Oktober & 1000,6 & 9111,2 & 29,3 \\
\hline April & 1871,7 & 18104,0 & 18,7 & November & 855,5 & 1271,3 & $-10,6$ \\
\hline Mei & 1652,6 & 15110,2 & 24,9 & Desember & 353,6 & 750,5 & $-31,3$ \\
\hline Juni & 1717,7 & 2181,8 & $-3,5$ & Total & 10813,1 & 129982,1 & \\
\hline Juli & 342,0 & 1424,4 & $-60,8$ & Rataan & 901,1 & $10,7581,8$ & \\
\hline Agustus & 1650,6 & 1797,1 & 11,8 & 2010 & & & \\
\hline September & 1175,5 & 10117,6 & 32,3 & Januari & 1150,8 & 1482,2 & $-10,7$ \\
\hline Oktober & 1349,3 & 12112,4 & 27,2 & Februari & 914,0 & 1091,4 & $-1,5$ \\
\hline November & 706,7 & 888,3 & 3,1 & Maret & 954,1 & 1373,4 & $-19,5$ \\
\hline Desember & 530,0 & 688,3 & 3,1 & April & 1283,1 & 12106,9 & 14,0 \\
\hline Total & 12953,6 & 1511023,0 & & Mei & 928,7 & 1092,9 & 0,0 \\
\hline Rataan & 1079,5 & $12,685,2$ & & Juni & 1343,8 & 9149,3 & 56,4 \\
\hline 2008 & & & & Juli & 808,9 & 1267,4 & $-25,5$ \\
\hline Januari & 572,3 & 871,5 & $-11,7$ & Agustus & 859,2 & 1178,1 & $-14,8$ \\
\hline Februari & 1102,8 & 1291,9 & 8,6 & September & 1126,1 & 1293,8 & 1,0 \\
\hline Maret & 981,3 & 1565,4 & $-17,8$ & Oktober & 762,2 & 984,7 & $-8,2$ \\
\hline April & 1506,2 & 14107,6 & 24,3 & November & 740,1 & 7105,7 & 12,8 \\
\hline Mei & 1723,7 & 16107,7 & 24,5 & Desember & 621,0 & 788,7 & $-4,2$ \\
\hline Juni & 1034,6 & 1379,6 & $-3,7$ & Total & 11492,0 & 1261114,6 & \\
\hline Juli & 920,3 & 1183,7 & 0,4 & Rataan & 957,7 & $10,592,9$ & \\
\hline
\end{tabular}




\section{KESIMPULAN}

a. Potensi lestari ikan julung-julung di perairan Tagulandang adalah 11,716 ton per tahun dengan upaya optimum 144,643 trip.

b. Musim penangkapan ikan julung-julung di perairan Tagulandang terbagi atas dua fase yakni menjelang pertengahan tahun, terjadi pada awal bulan April dan fase menjelang akhir tahun, terjadi pada bulan September dan Oktober.

\section{DAFTAR PUSTAKA}

Gulland, J.A. 1983. Fish stok assessment. A manual of basic methods. John Wiley and Sons, New York.

Handoyo, K. 2011. Sistem informasi pengelolaan sumberdaya dan lingkungan perikanan tangkap di Kabupaten Padang Pariaman, Sumatera Barat. Institut Pertanian Bogor. Bogor.

Nazir, M. 1985. Metode Penelitian. Ghalia Indonesia, Jakarta.

Reppie, E. dan A. Luasunaung. 2001. The status of roundscad net (talang) in Pahepa Island, Sangihe Talaud, North Sulawesi. Dalam: O. Carman, Sulistiono, A. Purbayanto, T. Suzuki, S. Watanabe and T. Arimoto (Eds). Proceedings of the 4th JSPS International Seminar on Fisheries in Tropical Area. Sustainable Fisheries in Asia in the New Millenium. 21-25 August 2000, at the Faculty of Fisheries and Marine Sciences, Bogor Agricultural University, Java Island, Indonesia. TUF International JSPS Project Vol. 10:181-186.

Reppie, E. and L.Th.X. Lalamentik. 2000. Artisanal fisheries in the Bunaken National Park of North Sulawesi,
Indonesia. Dalam: T. Arimoto dan J. Haluan (Eds). The 3rd JSPS International Seminar on Fisheries Science for Sustainable Fishing Technology in Asia toward the 21st Century. Bali Island - Indonesia 19-21 August 1999. TUF International JSPS Project. hal. 161-166.

Reppie, E., E.P. Sitanggang, dan J. Budiman. 2011. Pendugaan potensi dan musim penangkapan ikan julungjulung (Hemiramphus sp.) berdasarkan hasil tangkapan soma giop di perairan Selat Bangka, Kabupaten Minahasa Utara, Sulawesi Utara. Pacific Journal Regional Board of Research North Sulawesi 1(6): 1010-1014.

Schefer, M. 1954. Some aspects of the dynamic of populations important to the management of the commercial marine fisheries. Bull. I-ATTC/BOll. CIAT 1(2): 27-56.

Simbolon, D. 2011. Bioekologi dan dinamika daerah penangkapan ikan. Departemen Pemanfaatan Sumberdaya Perikanan. Fakultas Perikanan dan Ilmu Kelautan. Institut Pertanian Bogor, Bogor.

Sparre, P., S.C. Venema. 1999. Introduksi pengkajian stok ikan tropis. Diterjemahkan oleh Pusat Penelitian dan Pengembangan Perikanan.

Sumlang. 2009. Pendugaan potensi dan analisa musim penangkapan ikan julung-julung dengan soma roa di perairan Selat Bangka Kab. Minahasa Utara. Fakultas Perikanan dan Ilmu Kelautan, Universitas Sam Ratulangi, Manado.

Uktolseja, J.C.B. 1993. Status perikanan ikan pelagis kecil dan kemungkinan pemanfaatannya sebagai ikan umpan hidup untuk perikanan rawai tuna di Prigi, Jawa Timur. Jurnal Penelitian Perikanan Laut 80: 18-45.

Widodo, J. dan Sunardi. 2006. Pengelolaan Sumberdaya Perikanan Laut. Gajah Mada University Press. Yogyakarta. 